\title{
Blok, Vincent: Heidegger's concept of philosophical method: innovating philosophy in the age of global warming
}

\author{
Routledge, New York, 2020, ISBN: 9780367418120
}

\section{Wessel Reijers ${ }^{1}$}

Accepted: 21 September 2020 / Published online: 30 October 2020

(c) The Author(s) 2020

\begin{abstract}
This review discusses Vincent Blok's book Heidegger's Concept of Philosophical Method. Blok's daring and important argument is that Heidegger has been misunderstood by contemporary philosophers who dismiss his thinking as correlationism; but that at the same time there lies something at the core of Heidegger's thinking that prevents it from unleashing its true innovative potential; namely a logic of unity. To move beyond this logic of unity, Blok aims to rediscover and redefine the potential of Heidegger's philosophical method by characterising it along the lines of interrogative intention and creativity of world-interest. This move allows Blok to think about Earth in the age of global warming in a way that was not possible in Heidegger's work, providing a positive concept of the Earth's materiality as uncorrelated being that guides the way to a future environmental ethics. The review discusses the main contributions of the book, and also three criticisms, which concern the justification of choices for certain perspectives, the unfulfilled promise of moving from philosophical theory to more practically oriented guidance, and unclarities concerning the alternative that Blok puts forward as an answer to his criticism of Heidegger's method.
\end{abstract}

Keywords Blok $\cdot$ Heidegger $\cdot$ Philosophical method $\cdot$ global warming $\cdot$ Earthbound confrontation

Wessel Reijers

wessel.reijers@eui.eu

1 Robert Schuman Centre, European University Institute, Florence, Italy 
We live in a time of unprecedented change. At the moment of writing, many of us find ourselves in the middle of a lockdown, caused by the emergence of a global pandemic. In the blink of an eye, economic, social, and political structures that seemed set in stone have been shaken on their foundations. ${ }^{1}$ Humanity has also shown in the past months that it is capable of radical adaptation, and also of a transformation of thinking. We can change our way of life, though the conditions for this change seem ominous. Yet, will the ad hoc nature of our current upheaval lead to something more lasting, to a transformation of our way of thinking? The virus might have shaken up public and private life for a while, but after the shaking we might expect a bouncing back. Once the virus has been defeated, the old logic of technological innovation, economic growth, financializaton, and shareholder value might very well re-emerge. In other words, we still find ourselves in the epoch of modern technology and "enframing," in which the world is revealed as standing reserve; material to be used up. ${ }^{2}$ The question that we ought to ask, before the bouncing back happens, is how we can "grasp the day" and move beyond reactive and towards transformative thinking. It is with this question in mind that we can situate Vincent Blok's book in the current academic discourse.

Heidegger's Concept of Philosophical Method revives a discourse focused on innovative philosophical thinking; on moving beyond the metaphysical tradition. Blok's daring and important argument is that Heidegger has been misunderstood by contemporary philosophers who dismiss his thinking as "correlationism"; but that at the same time there lies something at the core of Heidegger's thinking that prevents it from unleashing its true innovative potential; namely a "logic of unity." To move beyond this logic of unity, Blok aims to rediscover and redefine the potential of Heidegger's philosophical method by characterizing it along the lines of "interrogative intention" and "creativity of world-interest" (p. 256). This move allows Blok to think about Earth in the age of global warming in a way that was not possible in Heidegger's work, providing a positive concept of the Earth's materiality as uncorrelated being that guides the way to a future environmental ethics (p. 289).

The book's introduction starts with a bird's eye overview of the development of philosophy between the early twentieth and early twenty-first century. Blok takes speculative realism as the main contemporary force of innovation in philosophy, for it has originally uncovered the implicit "correlationism" in philosophy; the assumption that we can only ever have access to the correlation between thinking and beingmaking it impossible to say anything positive about "uncorrelated" reality. However, in an original and important countermove, Blok situates in the midst of this will towards speculative innovation a fundamental problem that mirrors Husserl's diagnosis of the crisis of the sciences, namely the "indifference towards philosophical method" (p. 13). That is, the speculative realists have succeeded in criticizing correlationism, but have in doing so been uncritical with regards to their own philosophical method that should lead to an alternative way of doing philosophy. As a response, Blok's overall proposal is that "post-Heideggerian philosophy in the age of global warming should start with the question about philosophical method, and critically engage with various Heideggerian concepts like will, art, and Earth" (p. 19).

\footnotetext{
${ }^{1}$ Coeckelbergh (2020).

${ }^{2}$ Heidegger (1977).
} 
Blok proceeds in Part I (Chapters 1-4) with analyzing Heidegger's philosophical method. He departs from Heidegger's criticism of the "theoretical attitude" in Husserl's phenomenology (p. 37), which is not objective, but rather pre-structures how we access phenomena, namely as beings "present-at-hand" that stand over against us as investigators. He then elaborates the three main characteristics of Heidegger's method. First, it is characterized as a questioning, which "does not ask about beings but withdraws from these beings in order to have an indirect view of the relation between being and thinking, that is, the whole of being" (p. 66-original emphasis). Blok defends the primacy of questioning in the early Heidegger against attacks by Derrida and the later Heidegger, arguing against the idea that it involves a "circular argument" that does not break with the tradition (p. 73) and that it is an "intrusion of willing" (p. 77). Out of this discussion, Blok puts forward a novel interpretation of questioning as "the actual interrogative intention and creativity to explore the whole of being” (p. 81). Second, Heidegger's method is characterized as religionized reason. Against criticisms of Derrida and Meillasoux, Blok shows that Heidegger rejects the ordinary understanding of religion as a doctrine of finding answers, and instead opposes it to philosophical thinking; in which faith, nonetheless, still plays a role. As such, philosophical thinking involves relinquere, understood as "bidding farewell to ourselves as representing subjects" (p. 120). Third, Heidegger's philosophical method is characterized as explorative confrontation, in a fascinating back-and-forth between an interpretation of Nietzsche's nihilism, which involves the "nihil of the transcendental idea" in the metaphysical tradition, and Heidegger's confrontation with Nietzsche's guiding question (p. 135). Confrontation is contrasted with interpretation, in that it departs from the pre-understanding of being and rejects a fixed "standpoint" (p. 136) in favor of a confrontation of our essence in which thinking is already included, which therefore needs to depart from a basic experience of the meaning of being.

Part II turns to the question of the will, with the intention to develop a critique of Heidegger's philosophical method; focusing on the central problem of the "logic of unity." Against Derrida and Davis, Blok argues that Heidegger's notion of the will was not a sign of "massive voluntarism" (p. 152), but rather a straightforward result of the application of his method. However, Blok argues that Heidegger in applying his method of explorative confrontation brings forth a circularity between the method and its object of research. This means that the setting out-of-one-another is established as unbridgeable in Heidegger's method, but is at the same time constructed in such a way that it results in a new unity (p. 167). Touching upon gestalt psychology and affordance theory, Blok suggests a rethinking of Heidegger's method in a way that is open to an interrogative intention and creative world interest as a promising path towards philosophical innovation and a tentative move beyond Heidegger's highly problematic politics (p. 189). But is philosophy the answer? Blok examines how Heidegger in his later work turned to art and poetry as transitional for the other beginning of philosophy (p. 196). In opposition to the world of machination in which metaphysical thinking finds its highest point, a work of art inaugurates a "clearing of being" (p. 212), found in a strive between the concealment of Earth and the unconcealment of world. Poetry, then, is put forward as that which founds a new beginning (beyond machination), by delineating a world that is "not yet" and 
being the ground and commencement of the new beginning. However, Blok shows that Heidegger's notion of poetry tends to converge in the end with his notion of philosophy, which has the consequence that the problem of the logic of unity is not surpassed but reintroduced. With this, Blok rehabilitates the role of philosophy, leading him to the final part of the book in which he conceptualizes a renewed philosophical method based on a rethinking of Heidegger's work.

Chapter 7 concludes the book's journey, with a conceptualization of post-Heideggerian philosophical method as "earthbound confrontation" (p.262). Blok starts with a problematization of philosophy in the time of global warming, arguing that instead of problematizing our capacity for self-understanding and questioning of our place on Earth, global warming requires us to focus on Earth as ontic-ontological condition of our being-in-the-world. This means that we have to go along some way at least with the speculative realists, in acknowledging that philosophy needs to account for the uncorrelated being that is included in the concept of Earth; to account for the potential end of human existence. Blok shows that even though Heidegger went some part of the way, in acknowledging the uncorrelated being of Earth, he makes a metaphysical mistake in only characterizing Earth in terms of our access to it (p. 272). As a response, Blok develops five principles that capture the materiality of Earth. First, Earth's "conativity," which relates to the effort to differentiate material identities out of the undifferentiated (concealed) materiality in which they are embedded (p. 277). Second, Earth's non-identity consists of the undifferentiated origin of the identity of differentiated material entities (p. 279). Third, Earth's responsiveness, drawing from affordance theory, denotes that material entities are co-constituted by their responsiveness to affordances of other material entities in the environing world (p. 283). Fourth, Earth's performativity brings the first and third principles together in the actual "behavior" of material entities (p. 289). Fifth, Earth's eventuality denotes the misalignment between the stability of material entities and the inherent instability of the Earth, which leads to the possible destruction of the current world and emergence of new worlds (p. 289).

Heidegger's Concept of Philosophical Method deserves a central place in contemporary thinking on innovation in philosophy. Next to opening up an original direction of research, I believe in manages to make two central contributions.

First, the book opens up the much-neglected theme of philosophical method, which can be expanded beyond speculative realism and towards other corners of contemporary philosophy. I am thinking here, as an illustration, about the field of philosophy of technology and approaches such as Postphenomenology. Postphenomenology has been explicitly concerned with the consequences of classical philosophy of technology (e.g., Jaspers, Heidegger, Ellul) for our thinking about humantechnology relations. It has done so by drawing our attention to the great variety or multistabiliy of these relations. ${ }^{3}$ Yet, with Blok, we might ask whether Postphenomenology, like speculative realism, has not also neglected the question of philosophical method. In articulating motivations for going beyond classical philosophy of technology, of negating its "pessimism," "nostalgy," and "monolithic" conception

\footnotetext{
${ }^{3}$ Ihde (1979).
} 
of "technology with a capital T," Postphenomenology has put questions of method aside and instead has started to be preoccupied with things, with analyzing those various human-technology relations in our world. I believe that Postphenomenology is only one approach out of many that shows this disregard to philosophical method; and Blok's book is a forceful call to action to start paying attention to this issue in all corners of contemporary philosophy.

Second, Blok has made a start in linking innovation in contemporary philosophy to real world problems and their possible resolutions. I am of course in particular thinking about climate change, which as a problem has been certainly well understood scientifically, but not yet philosophically. In this perhaps somewhat unHeideggerian turn (since Heidegger was highly critical of this perhaps rather "Marxist intention" to mobilize philosophy to change the world) Heidegger's thought is becoming more relevant for practical philosophy. Even though scholars of environmental science might find the book difficult to access, I believe it offers a great pallet of ideas and insights that can be taken up in more concrete work that aims to tackle the problem of climate change, in environmental ethics, sustainable policy making, and the engineering sciences focusing on sustainable change.

Blok's book is undoubtedly a "diamond" in terms of its value for future philosophical research. Yet, this diamond also has a certain "rawness" to it, which leads me to three particular points of critique.

First, some choices made in the book I think are insufficiently justified. I will here focus on one such a choice, namely the characterization of "contemporary philosophy" by means of a discussion of speculative realism. At the start of the introduction, Blok turns to speculative realism by stating that the "conceptualization of the contemporary crisis," that is, the crisis of philosophical subjectivism, "can be found in the work of speculative realists like Quentin Meillassoux" (p. 4). This is a valid statement, but also immediately raises the question: Cannot similar criticisms be found elsewhere in "contemporary philosophy"; perhaps ones that do pay attention to philosophical method? Speculative realism is only one approach amongst many in the current philosophical landscape, and I believe others have addressed subjectivism with equal validity. I am hereby for instance thinking of Yuk Hui, ${ }^{4}$ who approach this difficulty through the lens of thinkers such as Simondon; or scholars like Alberto Romele, ${ }^{5}$ who in developing the notion of digital hermeneutics have tried to surpass the alleged subjectivism through the lens of a Ricourian critique of Heidegger. ${ }^{6}$ I am not claiming here that these directions should be incorporated in the critique; but rather that the choice for speculative realism as the primary representative of contemporary philosophy in the diagnosis of the problem of philosophical subjectivism is insufficiently justified in the book.

Second, the book leaves the reader with a sense of incompleteness in the end. The promise made in the introduction is that the reflections on Heidegger's philosophical method will gain a sense of relevance and urgency (p. 29) by contributing to

\footnotetext{
${ }^{4}$ Hui (2016).

5 Romele (2019).

6 Ricoeur (1983).
} 
a reflection on global warming; thus, discussing a concrete problematic, the most urgent of our time. One would have expected here a translation from the relative abstractness of the first parts of the book into a more practical discussion of how the earlier investigations could contribute to ongoing practical debates in environmental ethics and related discourses on the problem of climate change. However, the actual problem of climate change does not get much definite shape, only being briefly touched upon (p. 274). At the same time, the last chapter contains perhaps the most dense and complex exposition in the book, concerning an ontological concept of the materiality of earth in the age of global warming. Even though the steps taken in this chapter seem necessary, it would have been helpful for any reader looking for the aforementioned translation from philosophical theory to practical guidance, to have been presented with a more accessible sense of what the argument in the book could mean for our practical engagement with the relevant and urgent matter of climate change. As the book currently stands, the interests of environmental ethicists and earth scientists (p. 21) might not be adequately met.

Third, the "rawness" of the book raises some questions for clarification. On the one hand, Blok goes to great pains to elaborate on his interpretation of Heidegger's philosophical method; which can be illustrated by a passage such as in chapter six (p. 230) in which the characterization of poetic naming as "bestowing grounding" is explained in five different ways-extending to the point of becoming repetitive. On the other hand, the exposition of Blok's alternative, offered in response to his critique of Heidegger, remains rather thin. In several points in the book, the reader is redirected to the interrogative intention and creativity to explore the whole of being in chapter 2, but this exploration only covers two pages and consists of a high level reflection on the hierarchy between the ability to listen and the ability to question ( $\mathrm{p}$. 79). How, in this context, are we to understand the concepts of creativity and interrogative intention? Creativity as such is nowhere thematized explicitly in the book. It is "informed" by other discussions, such as the discussion on the "ampliative nature of willing" (p. 187), but how this informing unfolds into a characterization of the concept remains unclear. Furthermore, the notion of interrogative intention is later encountered in a confrontation with affordance theory. Yet, there Blok pleads for a shift from intention to attention (p. 184); it being impossible "to separate the attention of the one who wills for the affordance of that which is willed from the intention that the affordance provokes." How, in this context, are we to understand the notion of interrogative intention?

This brings me to the final point, of questioning the way in which affordance theory is used to pave the way to a post-Heideggerian philosophical method. In an earlier paper, ${ }^{7}$ Blok discusses the crucial relation between affordance theory and Heidegger's fundamental Ontology more in detail. My main concern is with the notion of action in affordance theory, ${ }^{8}$ for instance the chair affording the action of sitting,

\footnotetext{
7 Blok (2014).

${ }^{8}$ Blok (2014, p. 320).
} 
or the prey affording the action of hunting of the hunter. In reflecting on the Question Concerning Technology, Blok points at Heidegger's claim that phusis is poeisis and that techne belongs to poeisis, and as such is a bringing-forth. From this, he claims that for Heidegger, "techne and phusis are essentially the same." This conclusion allows Blok to consider techne as a demand of nature, which can be conceived as an affordance. However, Heidegger explained that techne has two meanings: As poetic activity, belonging to poeisis, and, more importantly as knowledge, or a way of revealing. ${ }^{10}$ By considering affordances in terms of action, or behavior-including even behaviors of entities other than Dasein such as stones and trees (p. 282) - it seems to me that the first sense of techne is appealed to. Yet, as Heidegger emphasizes, it is in the sense of revealing that techne is a bringing-forth.

These points of critique, I believe, do not challenge the argument in the book as such, but rather open up a question for clarification and future research. The raising of such a question is perhaps in fact another core quality of the book, for it illustrates how it provokes thought in many different directions. I would like to conclude by emphasizing that Heidegger's Concept of Philosophical Method offers an impressive and, in all likelihood, sustainable contribution to the discourse on method in contemporary philosophy. I am looking forward to how it will lead the way in transforming our thinking in the current challenging times; hopefully also in building bridges between philosophy and the world of action—of policy making, planning, and politics.

Funding Open access funding provided by European University Institute - Fiesole within the CRUICARE Agreement.

Open Access This article is licensed under a Creative Commons Attribution 4.0 International License, which permits use, sharing, adaptation, distribution and reproduction in any medium or format, as long as you give appropriate credit to the original author(s) and the source, provide a link to the Creative Commons licence, and indicate if changes were made. The images or other third party material in this article are included in the article's Creative Commons licence, unless indicated otherwise in a credit line to the material. If material is not included in the article's Creative Commons licence and your intended use is not permitted by statutory regulation or exceeds the permitted use, you will need to obtain permission directly from the copyright holder. To view a copy of this licence, visit http://creativecommons.org/licen ses/by/4.0/.

\section{References}

Blok, Vincent. 2014. Reconnecting with Nature in the Age of Technology. Environmental Philosophy 11(2): 307-332. https://doi.org/10.5840/envirophil20149913.

Coeckelbergh, Mark. 2020. The Postdigital in Pandemic Times: A Comment on the Covid-19 Crisis and its Political Epistemologies. Postdigital Science and Education 19: 1-4.

\footnotetext{
9 Blok (2014, p. 321).

${ }^{10}$ Heidegger (1977, p. 13).
} 
Heidegger, Martin. 1977. The Question Concerning Technology and Other Essays. New York: Graland Publishing Inc.

Heidegger, Martin. 1996. Being and Time. Edited by J. Stambaugh. New York: State University of New York Press. https://doi.org/10.1017/CBO9781107415324.004.

Hui, Yuk. 2016. On the Existence of Digital Objects. Minneapolis: University of Minnesota Press. https:// doi.org/10.1017/CBO9781107415324.004.

Ihde, Don. 1979. Technics and Praxis. Dordrecht: D. Reidel Publishing Company.

Ricoeur, Paul. 1983. Time and Narrative-volume 1. Edited by K. McLaughlin and D. Pellauer. Chicago: The University of Chicago. https://doi.org/10.2307/1864383.

Romele, Alberto. 2019. Digital Hermeneutics. London: Routledge. https://doi.org/10.4324/9780429331 893.

Publisher's Note Springer Nature remains neutral with regard to jurisdictional claims in published maps and institutional affiliations. 